Leonard Cohen and Philosophy: Various Positions. Edited by Jason Holt. Chicago, Illinois: Open Court, 2014. xii, 281 pp. ISBN 978-0-8126-9856-5. Contents: Leonard Cohen as a Guide to Life / Brendan Shea - The Existential Cohen / Agust Magnusson - Why Cohen's Our Man / Wieland Schwanebeck - The End of the World and Other Times in The future / Gary Shapiro - Is Leonard Cohen a Good Singer? / Jason Holt - Covering Cohen / Adam Auch - Leonard and Lorca / Edward Winters - Irony as Seduction / Christopher Lauer - The Mystery of the Mirror / Lisa Warenski - Leonard Cohen on Romantic Love / Simon Riches - Hallelujah and Atonement / Babette Babich - Politics in Beautiful Losers / Steven Burns - Writing Poetry after Auschwitz / Pawel Dobrosielski and Marcin Napiórkowski - Doom and Gloom in a Cloistered Room / Liane Heller - Dear Heather in a Dark Space / Christopher Ketcham - Can You Touch Someone's Body with Your Mind? / Rachel Haliburton - Is a Tear an Intellectual Thing? / Liam P. Dempsey - The Prophetic Mr. Cohen / Timothy P. Jackson - Clouds of Unknowing / Bernard Wills - The Happy Memes of "Hallelujah" / Peter Stone.

In his opening remarks, editor Jason Holt suggests that the cultural positions of the poet and pop star are contradictory. Leonard Cohen, he furthers, is the exception to this rule: a duality between high and low art, a paradox. "The pop star-poet paradox isn't that Cohen writes poetry and popular music," he notes, "but rather that his songs count both as poetry and as popular music." This collection of essays, written by philosophers who share an enthusiasm for Leonard Cohen, analyzes his poetry and songwriting from the perspective of philosophical inquiry. Remarkably, this is easily achieved-if anything, too easily. Each essay makes a valid contribution to the volume, and perhaps by editorial design various themes emerge, are played upon, and recede for later consideration. The aims of the volume are clear. But why so easy?

Cohen was a poet and writer first-and perhaps foremost. From the inception of his writing career he was encouraged and celebrated by lifelong friends and colleagues Irving Layton and Louis Dudek, and was lauded by leading figures of Canada's literati. Metaphorically speaking, Cohen had come down from Westmount, the beneficiary of a privileged and relatively cultured upbringing. He drifted through a Bachelor of Arts at McGill University but on the strength of his poetry and reputation was admitted to Columbia University. With his literary credentials established, Cohen was the recipient of several arts grants. He had also secured the enduring loyalty of publisher Jack McClelland. 
For Cohen, music and songwriting weren't exactly afterthoughts, or for that matter simply a means of paying the bills (though it was) - but it did lead to international recognition. Cohen's second novel, Beautiful Losers (1966), attracted critical attention but sold poorly. Remarkably, Cohen was surprised to learn from Lou Reed that not only was he a fan of the novel, he owned one of the few copies that had made it to the US. Like Reed, Cohen hit upon popular music as a platform for autobiographical poetry. Bob Dylan's success with Columbia Records had elevated the poetical value of popular music lyrics, and the commercial viability of the singer-songwriter. Following several fortuitous introductions, particularly to Judy Collins, Cohen was signed by John Hammond to Columbia without hesitation. Collins' enthusiasm for Cohen's songwriting compensated for his lack of studio and concert venue performance experience. In Cohen's own words, once you signed with Columbia, "that was it" - he became a recording artist and performer with the full support of the label. Thereafter, LPs such as Songs of Leonard Cohen (1967) and The Best of Leonard Cohen (1975) were perennial selections of the Columbia Record Club. For Cohen, who felt that his audience and financial prospects were limited in the Canadian literary world, the combination of sophisticated poetry and folk music was at that time commercially viable. Hammond's instincts had once again been proved correct, though he himself found it difficult to produce Cohen. That job initially fell to John Simon, now recognized as one of the most important producers of the era.

What was also immediately evident in the early years of Cohen's songwriting career was the appeal of his songs to other artists: Judy Collins, Joan Baez, and later, John Cale, Jeff Buckley, Nick Cave, Jennifer Warnes, and Rufus Wainwright (to name but a few). Several of the essays in this volume, particularly those by Wieland Schwanebeck ("Why Cohen's Our Man"), Adam Auch ("Covering Cohen"), Babette Babich ("Hallelujah and Atonement"), and Peter Stone ("The Happy Memes of 'Hallelujah'”) inquire into the universality of Cohen's seemingly idiosyncratic themes and obsessions. What is clear from their analysis, however, is that the themes themselves were not the main attraction. The travails of human experience are not unique and infinite manifestations of love and loss are the essence of the popular music lyric. However, the doggedness of Cohen's inward, contemplative gaze is perhaps the most remarkable feature of his poetry and songwriting. Accordingly, a variety of Mariannes, Suzannes, and Christines populate the Cohen songbook, all of whom are actual individuals, not mere amalgams of trysts. Cohen, like many great singer-songwriters of the period, is brutally honest in his assessment of his own often flawed engagement with the commonalities of human experience. What attracts performers to the songs, these essays collectively suggest, is the resonant voice of Cohen, its authority, bemused rectitude, and intellectual integrity. His experience, despite its inimitable nature, is somehow relatable to a fairly wide audience - to us. It is also what makes Cohen an inviting prospect for philosophical inquiry. 
Several articles examine the shifting foundations of Cohen's imagination and heritage. The son of Jewish immigrants, Cohen was also attracted to the imagery, iconography, and texts of Christianity and the Catholic Church. In adulthood, like many in the Age of Aquarius, he was drawn to Eastern mysticism and in 1996 was ordained a Rinzai Zen Buddhist monk. These themes recur throughout the collection, particularly in essays by Brendan Shea, who also traces Cohen's existential themes to ancient Greek philosophy, and Agust Magnusson, who discusses Camus, Kierkegaard, democracy, Dostoyevsky, and resignation. Essays by Christopher Ketcham, Rachel Haliburton, and Liam Dempsey discuss cognitive theory, teleology, materialism, and theories of emotion. In some ways, these essays demonstrate that Cohen's lyrics and poetry could also serve as a kind of dream catcher for his generation. Similarly, essays by Christopher Lauer ("Irony as Seduction") and Lisa Warenski ("The Mystery of the Mirror") capture Cohen's corporeal attachments and obsession with sexuality, physical love, and through that, spiritual awakening in sexual embrace.

Holt has attempted to capture the paradoxical and mercurial in Cohen, organizing the book into relatively clear sections: existence, beauty, love, religion, and so forth. This is helpful. As philosophers, each writer focuses on a theme or two and draws out a few insights. On the other hand, it is a credit to Cohen, and perhaps Holt, that several themes and images skip across the essays, shifting in meaning despite efforts to gauge discernible certainties. He can't be pinned down. That is a characteristic of good poetry, but not always of philosophical inquiry. If the reader is left with anything lasting here, it is perhaps the resonance of a line or two. While the enduring popularity of the song "Hallelujah" creeps into most of the articles in one way or another, it is a phrase from Cohen's song "Anthem" (The Future, 1992) that holds the attention of these philosophers: "There is a crack in everything / That's how the light gets in." It is our mistakes, or travails and tragedies, which show us meaning. Written by others, that sentiment is trite. Cohen, however, excels at enigmatic summation where other writers might fail-the mundane, the material, made mystical. Perhaps it is this which attracts and draws interpreters, philosophers, and audiences to his revelation.

Many of the essays would not be out of place on an undergraduate reading list or lower graduate seminar. I suspect that this, too, is somewhat by design. Several essays may leave readers feeling that their authors have sacrificed depth of discussion for the sake of the collection. In contrast, the historical approach taken by Steven Burns in "Politics in Beautiful Losers," is a highlight of the volume. Burns locates Cohen's poetry and music in the context of Canada's cultural and literary landscape as it flowered in 1960s and early 1970s, and observes that Quebec politics in the aftermath of the Quiet Revolution was very much the backdrop of the infamous novel. In this regard, Cohen was an acquaintance not only of Hugh MacLennan, whose novel Two Solitudes (1945) dramatized Anglo-French relations in Montreal, but also of Mordecai Richler, whose Jewish experience of the city differed from his own. A young lawyer 
and intellectual named Pierre Trudeau, who dedicated his life to the defence of Confederation, was also a youthful acquaintance. Burns' historical perspective, in my view, is convincing and thought-provoking, highlighting the distinctiveness of Montreal in those turbulent years and Cohen's lifelong attachment to his birthplace.

Cohen's success must also be understood in the context of the CRTC's newly-minted Canadian content regulations (1971). Cohen's LPs found audiences in Canada and Europe, but in the US sales were lacklustre until I'm Your Man (1988). Similarly, Cohen's writings benefited from the nationwide promotion of homegrown literature. Subsequent to Expo 67, held in Montreal, and coincident with Trudeau's years as prime minister, the nation experienced a convulsion of nationalistic spirit. Burns' essay posits that Beautiful Losers, published just a year before, initially failed to find an audience, and remains an underappreciated existential satire. Considered gratuitous and obscene, absurd, surreal and without plot, its lack of acceptance was proof enough to Cohen, the writer, that his literary aspirations would find a wider acceptance in music. Nonetheless, a dark, tragic comedy, inhabited by individuals who are victims of both history and personal foibles, Beautiful Losers may be read as a pivotal moment in Canadian literature and interpreted as emblematic of Canada's national character at that time.

Readers may be a little frustrated at the scarcity of Cohen's verse directly cited in the book. To put it bluntly, there's not enough of it. To be fair, I suspect this is less a test of the reader's knowledge of "Cohen-alia" and more an effort to work within current copyright restrictions. While reading, keep an anthology of Cohen's poetry and lyrics at hand, or a browser open. Likewise, it is not surprising, at least to me, that there is little discussion of the music, and that is a shame. "Hallelujah" is arguably among the cleverest riffs in Canadian popular music and its aesthetic appeal cannot be contemplated without consideration of Cohen's harmonic and melodic language-simple though it may seem to be, it is not without nuance. Furthermore, though largely self-taught, Cohen was intensely interested in the effect of music on his audience and constantly fussed over production details and methods. Surely, this should be discussed correspondent to his aesthetic and philosophical "positions."

\section{David Montgomery}

York University 